\title{
Prevention and Management of Blood Disorders Under Shariah Guidance
}

\author{
Munira Borhany $^{1, *}$ and Qazi Shaikh Abbas Borhany ${ }^{2}$ \\ ${ }^{I}$ NIBD (National Institute of Blood Diseases and Bone Marrow Transplantation), ST 2/A Block 17 Gulshan-e-Iqbal KDA \\ Scheme 24 Karachi, Pakistan. \\ ${ }^{2}$ NDI, Shahadah al A'alamiyah, Al Hawzah al ilmiyyah, (Najaf, Iraq), M.A., LLM (Shariah) Mushir: Federal Shariat Court of \\ Pakistan.
}

\begin{abstract}
Objective: The purpose of writing this article is to convince the Muslim communities worldwide - the second largest religious entity of the world - to adopt modern medical steps, which provide safety and care.

Methods and Discussion: Irrespective of their education, Muslims are highly influenced by Islam. They never consider science equal to their religion; therefore, in Muslim countries it is very difficult for any government, authority or institution to enforce norms in the respective medical sector through acts or ordinances. Instead, the canon source of Shariah can communicate this message easily. The masses practice their daily affairs as per Shariah as they believe that Shariah is the fountain of divine wisdom. Providing Muslim religious sources in this research paper is purely to communicate a scientific study under the guidance of Shariah to the community worldwide.

Conclusion: It is hoped that numerous Muslims would take advantage from it. The Ulama [Muslim clergy] and Madrasahs [Seminaries] have a pivotal role in influencing health education and its promotion amongst members of the Muslim community. They can provide potential access to people for raising, understanding and encouraging the use of health services as well as ethnic blood donor drives.
\end{abstract}

Keywords: Blood diseases, Muslims, Shariah, Prevention.

doi.org/10.21089/njhs.21.0002

\section{SAVING HUMAN LIFE, AN ISLAMIC VISION}

The saving of human life is considered to be one of the highest merits in Islam. The Qur'an says [1]:

"and he who saves a human life, it shall be as though he saved the entire humanity."

The majority of Ulama consider transplantation method Halal [permissible] from Muslim and non-Muslim donors based on the principle that the needs of the living supersede those of the dead. This practice is becoming accepted in Muslim countries. Drawing and transfusing blood and blood products is permissible, both from Muslims and non-Muslims.

\section{PREVENTION OF GENETIC DISORDERS}

Genetic disorders due to family marriages are common medical conditions in many countries. The conclusion of the discussion of Dr. Al Aqeel is as follows: [2].

*Address correspondence to this author at the Department of Haematology $\&$ Blood Transfusion. NIBD (National Institute of Blood Diseases and Bone Marrow Transplantation), ST 2/A Block 17 Gulshan-e-Iqbal KDA Scheme 24 Karachi, Pakistan. Tel: 92-21-34821502-3;

E-mail: muniraborhany@gmail.com
Strategic approach of cure for hereditary health disorders should be handled by adopting methodology of the Shariah, which is the canon source of Islam and provides us with a weighing scale on which one can judge each matter. Similarly, principles of the Shariah help seekers of guidance, irrespective of subject, time and place.

Diseases like thalassemia, are a heterogeneous group of inherited anemia's characterized by defects in the synthesis of one or more of the globin chain subunits, the hemoglobin tetramer. Thalassemia syndrome is seen in all ethnic groups and geographic areas but is most common in the Mediterranean region. Homozygous state manifests as Beta Thalassemia Major, leading to transfusion dependent anemia. Heterozygotes (Thalassemia minor) are carriers. Prevalence rate of carriers ranges between 4 and $8.0 \%$ in different regions and ethnic groups. Carriers are clinically normal but they can genetically transmit the disease to the next generation. If a couple has a thalassemia trait, there is $25 \%$ chance in every pregnancy that the offspring will be thalassemia major [3]. Hemophilia - a sex-linked hereditary coagulopathy - occurs due to the deficiency of clotting factors VIII and IX (hemophilia $\mathrm{A}$ and $\mathrm{B}$, respectively). The hallmark sign of hemophilia is painful bleeding in joints, muscles and body tissues leading to chronic inflammation and disability [4]. Similarly 
as a result of family marriages, rare autosomal recessive disorders like congenital coagulation bleeding, platelet functional disorders and type III Von Willebrand Disease (VWD) become common and run in families and tribes. In certain instances many kindred within an extended family or a tribe are commonly seen with phenotypic expression of the disease. The subsequent inbreeding, however, leads to increased homozygosity, which, in turn, leads to an increased risk of premature morbidity and mortality among the offspring. One possible method to prevent the spread of these diseases is pre-marital blood screening amongst all intending couples in order to safeguard the institution of marriage and to decrease the burden of disease in the community.

AIDS and Hepatitis: These are dangerous health hazards that have captured global attention. The spread of these is quite alarming, and if not controlled, may result in an epidemic. It transmits among people through sexual reunion, transfusion of blood and blood related products, use of nonsterilized syringes, blades and from the mother to child through the placenta. It is regrettable that in the Muslim countries where claimants of modesty and chastity live, these diseases prevail. Non-official statistics of the health sector have discovered a large number of Muslim couples that are carrying the most deadly HIV and Hepatitis virus in their blood.

\section{NEED OF PRE-MARRIAGE SCREENING}

Since the disease is not visible, merely looking at the people cannot identify it. If a female intending to get married is asked to undergo blood screening, the intention is not to question her chastity and insult her but just to safeguard her future husband, family and the institution of marriage. Similarly, a male should also follow the same procedure keeping aside his ego. Transmitting the disease to the spouse is an offence and hiding the fact of being a carrier would tantamount to fraud. Both crimes are strongly punishable from the Shariah point of view. Those who violate the principal of medical ethics should be charged. Amir al Mumineen, Ali ibn Abi Talib, instructed in clear terms [5]:

"It is compulsory upon the Imam to arrest Fasiq Ulama and quack (fraudulent and ignorant) medical practitioner".

There are men that know very well that they are HIV/Hepatitis positive but deliberately insist on marrying and spending their private life with the help of condoms. This will reduce the risk of transmission of sexually transmitted infections ("STIs") and pregnancy but woman will not agree to the use of condoms throughout her life as she desires to have children, nor will the husband be able to restrain himself. Therefore, the woman will be at the risk of contacting HIV/ Hepatitis. Moreover, condoms don't completely eliminate the risk of transmission of STIs.

There are women who have lost their husbands due to such diseases. After the completion of Iddah [6] if they wish to re- marry, only pre-marital screening can save their future husbands and the rest of their families. This applies to the man as well. A woman can break her marriage through Khula [7] if her husband is subsequently discovered to be a carrier. The wife receives her Mehr [8] and the compensation due to the divorce.

Pre-marital screening is looked down upon and is likely to incite public uproar. Nonetheless, the issue of pre-marital screening should not be taken for granted because the very essence of marriage as a religious obligation is to regenerate and bring happiness to the family, not to eliminate and cause trauma to the family. In menses, foul blood releases, therefore, we can say that bleeding is discussed in the Qur'an. Study the following Ayah, which invites our attention towards scientific study of blood in women [9]:

"They ask you (O Muhammad) about menses. Say: This is a period of stress, therefore, withhold (yourselves) from women during menstruation and do not approach them until they have become clean again. Once they are clean you may have intercourse with them in the way Allah has commanded you. Allah loves those who are repentant and those who clean themselves."

Human intellect cannot reach the Hikmah [divine wisdom] of the Qur'an but medical research has proved that sexual reunion during menstruation is one of the major cause of transmission and spread of infections. A Hadith guides [10]:

"Establish Marriage-ties and re-generate so that I will be overjoyed upon you in the hereafter."

For blood screening to be a pre-requisite for the marriage contract, government should take serious action with the help of Constitutional Institutions to move for a new law in this regard. Why should we shy from it? For example, we have several members of the society who are ready to screen a maid or an employee, but when it comes to marriage, they resist it. Yes, those who are guilty of the crime will definitely shy away instead of being bold and taking up the test. It is the responsibility of intelligentsia to create healthy atmosphere, which help in building an energetic society. We strongly believe that pre-marital screening is:

- In the best interest of spouses

- In the best interest of the off-spring

- In the best interest of the community

- In the best interest of the institution of marriage

- In the best interest of the moral-fiber of the Muslim Ummah

\section{HOW INFECTED COUPLES ESTABLISH MARITAL TIES}

Infected couples are at liberty to marry but it is advisable that they use preventive steps to avoid pregnancy during sexual 
reunion, as the risk of transferring the virus from the mother to child is possible. Infected couples must take additional safety measures to avoid conception and to prevent the infection since the AIDS virus transforms inside the body and repeated infection could increase the growth of the disease. If one of the spouses is an AIDS/hepatitis patient, the other can refuse sexual intercourse since this has been medically recognized to be the most important cause in the communication of the AIDS virus. In case any healthy spouse approves sexual intercourse, sufficient safety measures should be taken to decrease the threat of infection and conception.

Transmission of AIDS through breast-feeding is rare. Yet, as per medical opinion, if the child has access to other choices, breast-feeding should be avoided. If choices are not accessible, it is in the child's interest to feed on the mother's milk, as the risk of virus by AIDS is a bit less compared to other diseases. Necessary health precautions are indispensible to prevent transmission of the virus, as the mother would not be considered a risk to her child. Such precautions ensure that her blood - in case of a cut or wound or during menstruation - would not enter the infant's blood stream or mucous membranes. The chance of the virus being found in mother's milk, saliva, sweat and urine is certainly low. The risk would only be eminent if the nipples are cut or cracked resulting in bleeding and hence, blood being taken in through the mouth along-with the milk by the infant.

Qur'an guides us on the two most important objectives of marital relationship. These are the preservation of chastity and the bond of love and compassion between the spouses. These objectives get lost if either one of the spouse is contaminated with a disease or is handicapped rendering him or her incapable of satisfying the natural urge of the other. In general, basic teaching of Islam regarding release of wife by way of Talaq is clear and that is an injunction of Qur'an: [11]:

"Keep her [wife] with kindness and release her with generosity [from marriage bond, in case of incompatibility]."

Marriage should not be a source of causing harm to the spouses or transgressing divine limits. If there is no option for dissolution on the ground of the above noted afflictions, this principle is certainly to be violated. Marriage proposal and engagement can be terminated if one of future partners has a history of mental illness in the family. From the Muslim point of view, the existence of communicable diseases and the need to take sufficient preventive care from contacting them is well documented. The following Hadith provides guidance on the prevention of disease [12]:

"Keep away from the (infectious) leper as you do [fear] from a lion."

A Hadith says [13, see Supplementary Material]:
"If you hear that there is an epidemic, do not enter it [place]; if the deadly disease breaks out where you are, do not leave it [place] to escape the deadly disease."

Al Kafi differs from what Al Bukhari has declared above. According to Al Kafi, Ubaydullah al Halabi asked Imam Jafar al Sadiq whether a person was allowed to move out of a place where plague had broken out. The Imam replied:

"There is no harm. Rasulullah(S) only forbade leaving a place which was situated in front of the enemy position."

These traditions highlight the significance of quarantine as a technique to avoid the spread of communicable and epidemic diseases, which are transmissible.

In addition, Islam is protective of the reproductive health of human beings and therefore forbids all source of corruption, which may lead to HIV and AIDS. The Qur'an says [14]:

"Women impure [corrupt] are for men impure [corrupt] and men impure are for women impure. And women of purity [clean] are for men of purity [clean]. And men of purity are for women of purity. These are not infected by what people say [falsely accusation]. For them, there is forgiveness and an honorable provision [sustain]."

If the screening result of couples is positive, they can choose alternatives as follows:

\section{i. Contraception and Sterilization}

Contraception technology is acceptable if both the spouses approve. Nevertheless, sterilization is not tolerable except when the health of the mother is in danger. Infertile couples spend money, time and energy to have a child. In such condition, when a couple already had more than two congenitally affected children and a minor number unaffected, they can then select sterilization and should consult prominent Muslim Jurists.

\section{ii. Adoption}

As per Shariah, an adopted child is not acceptable as an heir. Lineage is important for heir ship, where birth can take place from legal pregnancy that is only through marriage. The Qur'an says [15, see Supplementary Material]:

"Nor has He [Allah] made your adopted sons your [real] sons. These are your wordings which have no reality."

Islam considers the guardianship of orphans a good deed. The pedigree of the baby should remain to his actual father.

\section{iii. Donation of Sperm, Ovum or Pre-embryo}

With the help of un-natural processes like semen reserves and in vitro fertilization, barren couples worldwide take the help of these modern techniques. Shariah has restricted procreation to within wedlock, only between husband and wife and does not allow use of any of these technologies. 


\section{Iv. Diagnosis During Pregnancy and Permission of Abor- tion}

With the new techniques such as cell free fetal DNA from maternal blood, Chorionic villus sampling (CVS) and amniocentesis, it is now possible to diagnose congenital malformation, genetic diseases and chromosomal abnormality. CVS can be carried out during the $12^{\text {th }}$ week of pregnancy to detect suspected genetic and chromosomal defects. Similarly, amniocentesis can diagnose such defects, but at a later stage of pregnancy (14-16 weeks). The couple can approach for Shariah ruling from the concerned scholars for abortion methodology in case of a serious hereditary condition such as Thalassemia Major before 120 days of conception [16] See Supplementary Material.

\section{COUNSELING BY THE TRUSTWORTHY}

We discuss the issue under the guidance of these Ahadith: [17]:

i). "Religion (Islam) is sincere counseling and good advice."

ii). "The counselor should be trustworthy."

The meaning of trustworthy in the above Hadith is that he or she should be skilled and proficient in the field in which they are giving opinion.

A Hadith said [18]:

"If a person practices medicine without due knowledge then that person is liable."

A Hadith confirmed the value of experience [19]:

"No one is wise except through experience."

Besides this, the counselor should maintain absolute confidentiality of the patient(s) and family involved. A Hadith said [20]:

"Whoever guards the secrets of a Muslim, Allah will guard their secret in this life and on resurrection day."

The counselor should consider the religion of the patient when providing their best opinion and should not impose their view. Opinion should be in understandable wordings. No religion provides independence and liberty as much as Islam has granted. Qur'an says [21]:

"There should be no compulsion in religion"

\section{SUGGESTIONS UNDER GUIDANCE OF SHARIAH}

Shariah concentrates on prevention of the disease rather than cure. Islam encourages marriage and prohibits fornication and adultery. The Qur'an says [22]:

"O people! Safeguard yourselves with full awareness of divine laws before your Lord, who created you from a single soul, and from it created its mate, and from the two of them spread men and women in multitudes;"
An Ayah orders the unmarried to get married [23]:

"Marry of those who are single among you."

A Hadith explained [24]:

"Marriage is my tradition; those who shun my practice are not from me (my follower)."

STD (Sexually transmitted diseases) could be managed if sexual desires are followed through the institution of marriage, as directed by Islam and recommended by all religions. Fornication, adultery, and sodomy are great sins and highly punishable crimes, as per Shariah. Alcohol is completely prohibited, as well as any common chemical substance that can cause mental disorder and inherited irregularity. Similarly use of Tobacco causes abortion and hereditary anomalies. It is prohibited as per laws of the Shariah and many Fatwa [Ruling] have reiterated its prohibition [25].

Any substance that is going to be harmful to the baby (i.e. teratogenic) should be avoided as per the instruction of the following Hadith [26]:

"Do No Harm"

\section{CONCLUDING REMARKS}

A Muslim government is bound to provide its citizens all necessary protective health measures to keep them safe from diseases. In Iran, performing hemoglobin electrophoresis for the detection of Thalassemia carriers is now imperative for all couples before marriage. In Malaysia, as per law, couples proposing for marriage should get an HIV negative certificate from a government recognized institution since one great advantage of pre-marital screening is the potential of helping the concerned individuals to live fruitfully.

\section{AUTHOR'S CONTRIBUTIONS}

$\mathrm{MB}$ and $\mathrm{AB}$ drafted the manuscript and conceived the work. $\mathrm{AB}$ conducted the literature overview and both authors contributed to the discussion and debate. Both authors read and approved the final manuscript.

\section{SUPPLEMENTARY MATERIAL}

\section{[Ref. No. 13]}

[When plague broke out there and people began to flee, $\mathrm{Mu}$ hammad Rasulullah (S) directed:

"He, who fled from there, would be considered to have run away from a battlefield".

Muhammad Rasulullah (S) declared this because he did not want Muslims to desert their position. It is clear from the explanation given by Abi Abdillah al Imam Jafar al Sadiq that the reason why Muhammad Rasulullah (S) forbade fleeing from plague on a particular occasion was that he wanted 
to impress upon the Muslims that they must stick to their duty at battlefield and must not expose themselves to a bigger risk. He did not issue a general instruction that the Muslims should not take precautionary measures against plague and should simply sit awaiting what was in store for them. A Muslim is duty bound to protect his life and property. As the Hadith passed through a number of transmitters, it took the shape of a general rule as we find it in its present form in "Al Bukhari". Fortunately the real intention of Muhammad Rasulullah(S) has been disclosed by Imam Jafar al Sadiq, who naturally knew it better than anybody else, for he himself was a member of Ahl al Bait].

\section{[Ref. No. 15]}

[Mahram are those with whom marriage is not allowed, as per the Law of Islam]. It is permissible for a person to adopt a child, but the child is not considered his son or daughter; the child remains a stranger (non-Mahram) to him or his wife and he or she does not inherit the person who has adopted him or her. The child cannot use the name of the adoptee as his or her father. It should be noted that the relationship gained by the adopter and the adoptee cannot become Mahram. Adopted child should understand this Hadith:

"Mun Nasaba ila Ghaire Abehe Fa Alehe Lanah". The one who referred the lineage of other as his own [father's lineage], upon whom is my Lanah[curse-far away from the Rahmah-blessings of Allah].

\section{[Ref.No. 16]}

[The Fatwa of the Islamic Jurisprudence Council of the World Islamic League at its 12th session (10-17 February, 1990) in Makkah, agreed by a majority vote to allow for the option of abortion under certain specific conditions. The fatwa determined that an abortion may take place only if a committee of specialized, competent physicians has decided that the fetus is grossly malformed, and that its life would be a calamity for both the family and itself. The malformation must be untreatable, unmanageable and very serious, and the abortion may only be carried out prior to the 120th day of conception (computed from the date of fertilization, not the last menstrual cycle). On the basis of this Fatwa, abortions of serious congenital disease are carried out in the hospitals of Saudi Arabia.

Many dilemmas remain. Is it allowable to abort a Down syndrome fetus, which if carried to term and given birth, could likely live a quiet, peaceful and love-giving life? Is it acceptable to abort if the Huntington disease gene is detected - the disease is unlikely to appear until the person is 40 years, or even 60 years old? Is it permissible to abort those who are homozygous for sickle-cell disease or thalassaemia, or phenylketonuria or homocystinuria; the latter two diseases can be cured simply by avoiding foods containing phenylalanine or methionine? Similarly, treatment exists for the haemolytic anaemias by way of blood transfusion and iron chelation therapy.

The Islamic jurisprudence council of Makkah (the Islamic world League) passed a Fatwa No. 4 (Legal Resolution) in its 12th session held in 15-22 Rajab 1410H (10-17 February 1990) which allowed abortion if the fetus is grossly malformed with untreatable severe condition proved by medical investigations and decided upon by a committee formed by competent trustworthy physicians, and provided that abortion is requested by the parents and the fetus is less than 120 days computed from moment of conception.

Human life begins at the time of ensoulment, which is stated in the Hadith to be at 120th day from the moment of conception, which is equivalent to 134 days from the last menstrual period (LMP) used by obstetricians. Prior to that moment the embryo has sanctity, but not reaching that of a full human being.

This Fatwa was a landmark, as previous Fatwas only allowed abortion in the first 40 days of conception. At such a period it was almost impossible to ascertain any of the congenital or hereditary diseases. By extending the time of permissible abortion to 120 days computed the from moment of conception (i.e. 134 days from LMP), gives ample time to ascertain the diagnosis of severely affected embryo's and fetuses.

Ethical considerations in the prevention and management of genetic disorders with special Emphasis on religious considerations. Dr. Mohammed Ali Albar.

[Like many of the Sunni scholars, Shia Marja-e-Taqlid does not condone abortions on the grounds of expected illness or deformity. Shia Ithna Ashari Marja, Ayatullah Sistani has shares this view, sometimes the doctors reach the following conclusion: this fetus is afflicted with a very serious disease; it is therefore preferable that it should be aborted because if the child is born, it will be deformed or will die soon after birth. Is it, therefore, permissible for the doctor to abort the fetus? Is it permissible for the mother to agree to the abortion? And who of the two will become liable for indemnity?

Answer: Just the fact that the child will be deformed or that it will not live for a long time after his birth does not ever justify the termination of the pregnancy. Therefore, it is not permissible for the mother to consent to the abortion just as it is not permissible for the doctor to go ahead with the procedure. And whoever performs the abortion will become liable for the payment of indemnity]

\section{ACKNOWLEDGEMENT}

Declared none. 


\section{CONFLICT OF INTEREST}

Declared none.

\section{REFERENCES}

[1] The Qur'an: Ayah 32; Surah al Maidah-5.

[2] Al Aqeel AI. Islamic ethical framework for research into and prevention of genetic diseases. Nat Genet. 2007; 39(11): 1293-8.

[3] Bernard G. Thalassemia Syndromes. In: Hematology basic principles and practice. vol. 485: $3^{\text {rd }}$ edition. Churchill Living Stone: 2000; pp. 491-4.

[4] Lazier JN, Kessler CM: Clinical aspects and therapy of hemophilia. In: hematology basic principles and practice, $3^{\text {rd }}$ edition. Churchill Living Stone: 2000; 1883-9.

[5] Tehzib al Ahkaam, vol. 6, p. 319, Hadith 878; Mun La Yahzarah ul Faqhee, vol. 3, p. 31, Hadith 3266.

[6] Iddah= 4 months 10 days compulsory period of stay in seclusion for deceased's wife as per the injunction of Qur'an.

[7] Khula $=$ Wife's exclusive right of divorce in Muslim law, through which she can release her from marriage bond.

[8] Mehr= It is a compulsory gifted amount, decided prior to marriage and payable before conjugal act, among Muslims. See for details: Mehar: Neglected Rights of Wife, by Qazi Dr. Shaikh Abbas Borhany, www.durrenajaf.com

[9] The Qur'an: Ayah 222: Surah al Baqarah-2.

[10] Ibn Abi Jamhur, Muhammad bin Zainuddin, Awali ul Liyali al Aziziyyah Fil Ahadith al Diniyyah, vol 4, Dar Syed ash Shuhada,Qum,1405[AH].
[11] The Qur'an: Ayah 229: Surah al Baqarah -2.

[12] Mun La Yahzarah ul Faqhee, Ibn Babwe, Muhammad bin Ali, vol 3,p.557,Qum,Iran.

[13] Tib un Nabi, Mustaghfiri, Jafar bin Muhammad, vol. 1, Maktabat al Haidarriyyah, Najaf, Iraq, 1385 [AH]; 2- Al Kafi, Muhammad b. Yaqub al Kuleni Vol. VIII.

[14] The Qur'an: Ayah 26, Surah an Noor-24.

[15] The Qur'an: Ayah 4: Surah Al Ahzab-33.

[16] M.A. Albar. Counseling about genetic disease: an Islamic perspective, 1999; vol. 5(6): pp. 1129-33.

[17] Hadith: narrated by Al Bukhari and Al Muslim.

[18] Hadith: narrated by Abu Dawood.

[19] Hadith: narrated by Al Bukhari and Al Muslim.

[20] Hadith: narrated by Muslim; Nahj ul Fasahat, Abul Qasim Paindah, p. 725,Dunyae Danish, Tehran, Iran

[21] The Qur'an: Ayah 256: Surah Al Baqarah-2.

[22] The Qur'an: Ayah 1: Surah An Nisa-4.

[23] The Qur'an: Ayah 32: Surah An Noor-24.

[24] "Jame al Akhbaar", Shaeeri, Muhammad b. Muhammad, Matba Haidariyyah, Najaf. Iraq.

[25] For further references: Use of Tobacco in Islam, By: Qazi Dr. Shaikh Abbas Borhany. Retrived from: www.durrenajaf.com.

[26] Al Kafi, Muhammad b. Yaqub al Kuleni, vol. 5, p. 292, Qum, Iran. 